Research Article

\title{
HLA-DRB1 alleles in four Amerindian populations from Argentina and Paraguay
}

\author{
Maria L. Parolín and Francisco R. Carnese \\ Sección Antropología Biológica, Instituto de Ciencias Antropológicas, Facultad de Filosofía y Letras, \\ Universidad de Buenos Aires, Buenos Aires, Argentina.
}

\begin{abstract}
The major histocompatibility complex (MHC) is one of the biological systems of major polymorphisms. The study of HLA class II variability has allowed the identification of several alleles that are characteristic to Amerindian populations, and it is an excellent tool to define the relations and biological affinities among them. In this work, we analyzed the allelic distribution of the HLA-DRB1 class II locus in four Amerindian populations: Mapuche $(n=34)$ and Tehuelche $(n=23)$ from the Patagonian region of Argentina, and Wichi SV $(n=24)$ and Lengua $(n=17)$ from the Argentinean and Paraguayan Chaco regions, respectively. In all of these groups, relatively high frequencies of Amerindian HLA-DRB1 alleles were observed (DRB1 ${ }^{*} 0403$, DRB $1{ }^{*} 0407$, DRB $1{ }^{*} 0411$, DRB1 ${ }^{*} 0417$, DRB $1{ }^{*} 0802$, DRB1 ${ }^{*} 0901, \mathrm{DRB} 1{ }^{*} 1402, \mathrm{DRB}{ }^{*} 1406$ and DRB1* 1602 ). However, we also detected the presence of non-Amerindian variants in Mapuche (35\%) and Tehuelche (22\%). We compared our data with those obtained in six indigenous groups of the Argentinean Chaco region and in a sample from Buenos Aires City. The genetic distance dendrogram showed a clear-cut division between the Patagonian and Chaco populations, which formed two different clusters. In spite of their linguistic differences, it can be inferred that the biological affinities observed are in concordance with the geographic distributions and interethnic relations established among the groups studied.
\end{abstract}

Key words: HLA-DRB1, polymorphism, Amerindians, biological affinities.

Received: May 12, 2008; Accepted: September 5, 2008.

\section{Introduction}

In the human species, the major histocompatibility complex (MHC) includes the HLA (human leukocyte antigen) genes. It is located on the short arm of chromosome 6, between $6 \mathrm{p} 21.31$ and $6 \mathrm{p} 21.33$, and is characterized by a set of highly polymorphic genes. The function of the HLA genes is to present antigens to the T-cells. In addition, some of the class I genes are ligands for natural killer cell receptors. These histocompatibility molecules can be divided into two main groups: class I and class II molecules. Class I molecules are found in the HLA-A, HLA-B and HLA-C loci, and class II in the HLA-DR, HLA-DQ and HLA-DP loci. Both types of molecules are formed by heterodimers consisting of two chains, $\alpha$ and $\beta$, noncovalently bound to an extracellular domain, a transmembrane portion and a cytoplasmic tail (Fainboim et al., 1999; Travers, 2000).

One of the characteristics of the HLA system is its high degree of polymorphism. The extensive gene distribution among populations has enabled the characterization of different ethnic groups and the development of several in-

Send correspondence to Francisco R. Carnese. Sección Antropología Biológica, Instituto de Ciencias Antropológicas, Facultad de Filosofía y Letras, Universidad de Buenos Aires, Puán 470, 1406 Ciudad de Buenos Aires, Argentina. E-mail: antbiol@filo.uba.ar. teresting studies in bioanthropology. In this context, the analysis of the HLA system variability is an excellent tool for evolutionary studies, migratory path reconstruction, the establishment of interethnic contacts, and for evaluating the relationships and biological affinity among different human groups. These studies, conducted at the serological level and, more recently, with the use of molecular techniques, have shown that Native Americans display a lower genetic diversity than other populations (Cerna et al., 1993; Trachtenberg et al., 1996; Fernández-Viña et al., 1997; Salzano, 2002; Tsuneto et al., 2003). In addition, it has been observed that certain allelic variants found in Amerindians are absent or have lower frequencies in other ethnic groups. In Native Americans, the alleles DRB1 ${ }^{*} 0403,{ }^{*} 0404, * 0407, * 0802, * 0901, * 1402$ and *1602 are extensively distributed throughout America, whereas DRB1 *0411, *0417, *1406, and *1413 were detected mainly in indigenous populations of Latin America (Cerna et al., 1993; Zhang et al., 1993; Petzl-Erler et al., 1997; Tsuneto et al., 2003). A review on this subject was recently published (Salzano, 2002).

In Argentina, Pirosky et al. (1983), Vullo et al. (1984) and Haas et al. (1985) made serological determinations of the class I and class II HLA antigens in the Toba, Wichi and Mapuche groups, and molecular studies were performed 
mainly in some aboriginal populations of northern Argentina (Vullo et al., 1992; Cerna et al., 1993; Fernández-Viña et al., 1997, Pando, 1998; Marcos, 2000) and also in a Mapuche group of Anecón Grande, province of Río Negro (Ginther et al., 1993). However, there are no studies so far on the allelic distribution of HLA-DRB1 in Mapuche populations from the localities of Cerro Policía and Aguada Guzmán, in the Río Negro province, nor in the Tehuelche community of the province of Chubut. No studies were performed either in the Wichi groups of Santa Victoria Este, province of Salta, or in the Lengua community of the Paraguayan Chaco. Therefore, the aim of this study was: 1) to analyse the genetic diversity of the HLA-DRB1 locus in four Indian populations, two from the Argentine Patagonia region (Mapuche and Tehuelche) and the other two (Wichi and Lengua) from the Gran Chaco Region of Argentina and Paraguay, respectively; 2) to estimate the genetic distances among them; and 3) to compare the results obtained with those from other native groups of Argentina.

\section{Materials and Methods}

\section{Populations studied}

The Mataco or Wichi are much more numerous than the other Amerindian Chaco groups, their total population being estimated at 20,000 in 1986. A 1984 census revealed a total of 9,143 individuals in Salta, representing $51 \%$ of the Province's Indian groups. Besides agriculture, hunting and fishing, they are notable by their textile production (Acreche et al., 1996). Their language, Mataco proper, is classified within the Mataco-Guaicuru linguistic stock (Loukotka, 1968; Greenberg, 1987). The sample was obtained from the community of Santa Victoria Este (SV), Department of Rivadavia, province of Salta $\left(63^{\circ} 42^{\prime} \mathrm{W}, 22^{\circ} 17^{\prime} \mathrm{S}\right.$. See Figure 1)

The Lengua Indians live between $20^{\circ} 30^{\prime}$ and $24^{\circ} \mathrm{S}$ and $58^{\circ}$ and $59^{\circ} 50^{\prime} \mathrm{W}$. They previously lived in Bolivia, and their language is classified as a stock of the Chaco division (Loukotka, 1968) or, according to the classification by Greenberg (1987), the Macro-Panoan branch of the GePano-Karib division. In the past, their life depended upon hunting, fishing and gathering. Currently, the main population is settled in communities near Filadelfia, Department of Boquerón, Paraguay (Figure 1), where they cultivate small gardens, plant crops, and have some livestock (Goicoechea et al., 2001a). The individuals studied came from two communities, Misión Lengua, Barrio Obrero, Filadelfia, and Yalve Sanga, located $30 \mathrm{~km}$ south of Filadelfia.

The Mapuche speak a language classified within the Southern Andean division, the Araucanian group (Loukotka, 1968; Greenberg, 1987). They came from Chile and became established in Argentina since the beginning of the 17th century. Originally they mainly practiced agriculture, but nowadays they also extensively raise sheep and goats. They live in both rural and urban areas of the prov-

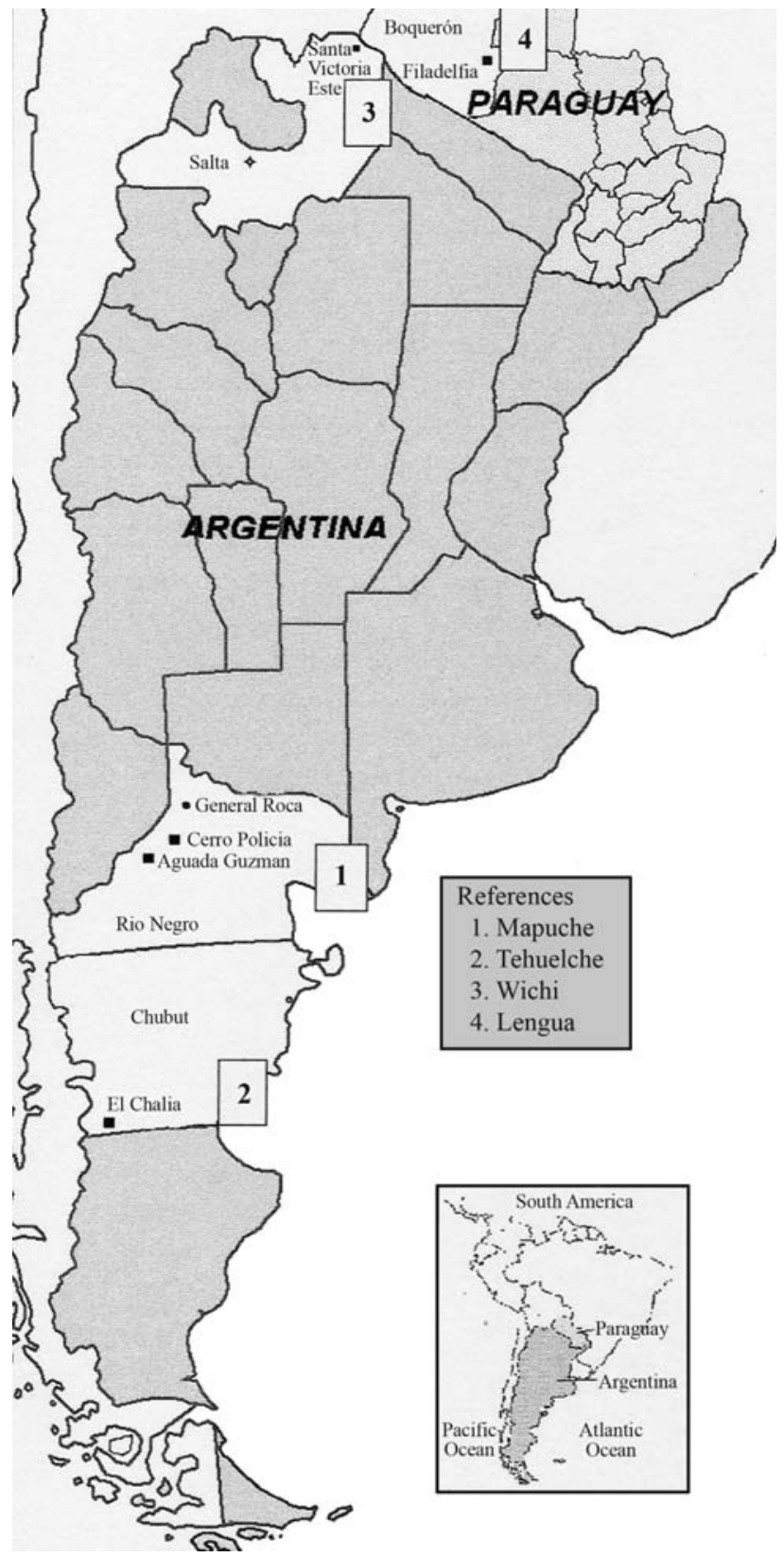

Figure 1 - Map of Argentina and Paraguay showing the geographic locations of the Amerindian populations analysed in this report.

inces of Rio Negro, Neuquén, Chubut, Santa Cruz, La Pampa and Buenos Aires. Their total population was estimated at 50,000 (Goicoechea et al., 1996). The present sample was obtained from two localities: Aguada Guzmán $\left(68^{\circ} 57^{\prime} \mathrm{W}, 39^{\circ} 30^{\prime} \mathrm{S}\right)$ and Cerro Policia (68 $37^{\circ} \mathrm{W}, 39^{\circ}$ $10^{\prime}$ S), province of Rio Negro (Figure 1).

The present-day Tehuelche are the remnants of a formerly quite large tribe that in historic times occupied the whole Patagonia, from the Rio Negro and its affluent, the Rio Limay, down to the Strait of Magellan and the isthmus connecting the Brunswick Peninsula with the continent. They were split into two main divisions, northern and southern, and those who live now are probably descendants of the southern group. Intermixture with non-Indians has 
occurred over the years (Valory, 1968). Their language is classified as Andean, Patagon stock (Loukotka, 1968; Greenberg, 1987). Material for the present study was collected at the village of El Chalia $\left(71^{\circ} \mathrm{W}, 45^{\circ} \mathrm{S}\right)$, Department of Rio Senguer, province of Chubut.

\section{Biological samples}

A total of 98 individuals of Amerindian populations from the Patagonia Region [Mapuche $(\mathrm{n}=34)$ and Tehuelche $(n=23)]$ and the Gran Chaco region of Argentina and Paraguay [Wichi SV $(\mathrm{n}=24)$ and Lengua $(\mathrm{n}=17)$ ] were analysed (Figure 1).

The blood samples were obtained during the period from 1990 to 1995. Blood was collected into sterile tubes with anticoagulant and codified, anonymized and kept at $-20^{\circ} \mathrm{C}$ in the DNA Bank of the Biological Anthropological Section of the Anthropological Science Institute of Buenos Aires University. The donors of the samples were informed about the aim of the study and gave their consent to perform the research. The Wichi and Lengua samples were provided by Dr. J. Ferrer from Pennsylvania University, USA. DNA was obtained using the organic extraction method with phenol-chloroform and ethanol precipitation. The allelic variants of the HLA-DRB1 locus were determined using the PCR-SSOP (Polymerase Chain Reaction-Specific Oligonucleotide Probes) and PCR-SSP (Polymerase Chain Reaction-Sequence Specific Primers) molecular typing techniques. At first, sequence amplification of exon-2 was performed using primers that match homologous sequences for all the alleles of HLA-DRB1 loci. These products were scattered in a dot-blot shape on a positively charged nylon membrane, then denatured, fixed and later hybridized to several SSOP probes marked with digoxigenin. This first typing recognizes only the DRB1 family of alleles. The oligonucleotides used as probes or primers and the hybridization protocols were obtained from the XII International Histocompatibility Workshop (Bignon and Fernandez-Viña, 1997). For the determination of the allelic subtypes, the Orelup PCR-SSP kit was used according to the manufacturer's instructions.

\section{Statistical analysis}

The HLA-DRB1 gene frequencies were estimated using the maximum likelihood method (Excoffier and Slatkin, 1995). Hardy-Weinberg (HW) equilibrium was tested by calculating the exact p-values as proposed by Guo and Thompson (1992), using the ARLEQUIN program, version 2000 (Schneider et al., 2000). Gene diversity and genetic distances (DA) were estimated using the method of Nei (1973, 1986) and Nei et al. (1983). Neighbour-joining dendrograms (Saitou and Nei, 1987) were elaborated using the DISPAN program (Ota, 1993).

\section{Results}

Table 1 shows that in the four populations studied the alleles of Amerindian origin presented several variations.
For example, while alleles DRB $1 * 1402$ and DRB $1 * 0802$ were detected in all groups analysed, allele DRB $1 * 0403$ was observed only in Wichi SV, Tehuelche and Lengua. The latter two groups shared the DRB1*1602 variant with the Mapuche Indians. However, in spite of the similarities detected, some of these variants presented different frequencies in the analysed groups. In turn, alleles DRB1*0411, DRB1*0417 and DRB1*1406 were detected only in the Gran Chaco region, while DRB1*0407 and DRB1*0901were detected exclusively in Patagonia.

Three out of the four populations were in HW equilibrium: Mapuche $(\mathrm{p}=0.07)$, Tehuelche $(\mathrm{p}=0.54)$ and Wichi SV $(p=0.11)$, whereas in Lengua there was a significant difference in the HWE $(p=0.02)$, with a pronounced deficiency of heterozygotes $($ Hobs $=0.36$, Hesp $=0.55)$. In Mapuche and Tehuelche, 15 allelic variants were found, followed by Wichi SV and Lengua with 6 and 5 variants, respectively. The indigenous people of Patagonia exhibited a greater genetic diversity, probably due to the introgression of genes of European origin into their gene pool. In fact, these populations presented $35 \%$ and $22 \%$ of nonAmerindian genes, respectively (DRB $1 * 01, \mathrm{DRB} 1 * 0301$, DRB1*0405, DRB1*0701, DRB1*1001, DRB1*1101,

Table 1 - HLA-DRB1 allele frequencies in the four populations studied.

\begin{tabular}{|c|c|c|c|c|c|}
\hline \multirow{2}{*}{$\begin{array}{l}\text { Alleles } \\
\text { HLA-DRB1 }\end{array}$} & & \multicolumn{4}{|c|}{ Populations } \\
\hline & & \multirow{2}{*}{$\begin{array}{c}\begin{array}{c}\text { Mapuche } \\
(\mathrm{n}=34)\end{array} \\
0.059\end{array}$} & \multirow{2}{*}{$\begin{array}{c}\text { Tehuelche } \\
(\mathrm{n}=23)\end{array}$} & \multirow{2}{*}{$\begin{array}{c}\text { Wichi SV } \\
(\mathrm{n}=24)\end{array}$} & \multirow{2}{*}{$\begin{array}{l}\text { Lengua } \\
(\mathrm{n}=17)\end{array}$} \\
\hline DRB1*01 & 01 & & & & \\
\hline DRB $1 * 03$ & 0301 & 0.059 & 0.022 & & \\
\hline \multirow[t]{5}{*}{ DRB1* 04} & $0403^{\wedge}$ & & 0.022 & 0.104 & 0.029 \\
\hline & 0405 & 0.029 & & & \\
\hline & $0407^{\wedge}$ & 0.205 & 0.325 & & \\
\hline & $0411^{\wedge}$ & & & 0.062 & \\
\hline & $0417^{\wedge}$ & & & 0.146 & \\
\hline DRB $1 * 07$ & 0701 & 0.059 & 0.022 & & \\
\hline DRB $1 * 08$ & $0802^{\wedge}$ & 0.089 & 0.108 & 0.021 & 0.059 \\
\hline DRB1* 09 & $0901^{\wedge}$ & 0.074 & 0.087 & & \\
\hline DRB1* 10 & 1001 & & 0.022 & & \\
\hline \multirow[t]{3}{*}{ DRB1* 11} & 1101 & 0.015 & 0.022 & & \\
\hline & 1102 & 0.029 & 0.022 & & \\
\hline & 1104 & 0.044 & & & \\
\hline DRB $1 * 12$ & 12 & & 0.043 & & \\
\hline \multirow[t]{2}{*}{ DRB1* 13} & 1301 & 0.029 & & & \\
\hline & 1302 & & 0.022 & & \\
\hline \multirow[t]{2}{*}{ DRB1* 14} & $1402^{\wedge}$ & 0.118 & 0.217 & 0.250 & 0.206 \\
\hline & $1406^{\wedge}$ & & & 0.417 & 0.647 \\
\hline DRB1* 15 & 15 & 0.015 & 0.022 & & \\
\hline \multirow[t]{2}{*}{$\mathrm{DRB} 1 * 16$} & 1601 & 0.015 & & & \\
\hline & $1602^{\wedge}$ & 0.161 & 0.022 & & 0.059 \\
\hline
\end{tabular}

n: number of samples; ${ }^{\wedge}$ : most frequent alleles in Amerindian populations. 
Table 2 - Geographic and linguistic origins of the Argentinean populations that were compared with the Amerindian groups studied.

\begin{tabular}{|c|c|c|c|c|}
\hline Population & $\mathrm{n}$ & Language & Locality & Reference \\
\hline \multirow[t]{2}{*}{ Chiriguano } & 56 & Tupí-Guaraní & Orán $\left(23^{\circ} 08^{\prime} \mathrm{S}, 64^{\circ} 20^{\prime} \mathrm{W}\right)$ & Pando, 1998 \\
\hline & & & Province of Salta & \\
\hline \multirow[t]{2}{*}{ Wichi (2) } & 19 & Mataco Guaicuru & Orán $\left(23^{\circ} 08^{\prime} \mathrm{S}, 64^{\circ} 20^{\prime} \mathrm{W}\right)$ & Pando, 1998 \\
\hline & & Mataco Division & Province of Salta & \\
\hline \multirow[t]{2}{*}{ Wichi (3) } & 49 & Mataco Guaicuru & Province of Formosa & Cerna et al., 1993 \\
\hline & & Mataco Division & (Ref: Mataco-Wichi) & \\
\hline \multirow[t]{2}{*}{ Toba (1) } & 135 & Mataco Guaicuru & Province of Formosa & Cerna et al., 1993 \\
\hline & & Guaicuru Division & (Ref: Eastern-Toba) & \\
\hline \multirow[t]{2}{*}{ Toba (2) } & 19 & Mataco Guaicuru & Province of Formosa & Cerna et al., 1993 \\
\hline & & Guaicuru Division & (Ref: Western-Toba-Pilaga) & \\
\hline \multirow[t]{2}{*}{ Toba (3) } & 86 & Mataco Guaicuru & Rosario city $\left(32^{\circ} 57^{\prime} \mathrm{S}, 60^{\circ} 39^{\prime} \mathrm{W}\right)$ & Marcos, 2000 \\
\hline & & Guaicuru Division & Province of Santa Fe & \\
\hline \multirow[t]{2}{*}{ Buenos Aires } & 365 & Spanish & Buenos Aires city $\left(34^{\circ} 38^{\prime} \mathrm{S}, 58^{\circ} 28^{\prime} \mathrm{W}\right)$ & Marcos, 2000 \\
\hline & & & Province of Buenos Aires & \\
\hline
\end{tabular}

Table 3 - HLA-DRB1 allele frequencies in six Amerindian groups of the Gran Chaco and a sample of Buenos Aires city.

\begin{tabular}{|c|c|c|c|c|c|c|c|c|}
\hline \multirow{2}{*}{$\begin{array}{l}\text { Alleles } \\
\text { HLA-DRB1 }\end{array}$} & & \multicolumn{7}{|c|}{ Populations } \\
\hline & & \multirow{2}{*}{$\begin{array}{c}\text { Chiriguano } \\
(\mathrm{n}=56)\end{array}$} & \multirow{2}{*}{$\begin{array}{c}\text { Wichi (2) } \\
(\mathrm{n}=19)\end{array}$} & \multirow{2}{*}{$\begin{array}{c}\text { Wichi (3) } \\
(\mathrm{n}=49)\end{array}$} & \multirow{2}{*}{$\begin{array}{c}\text { Toba (1) } \\
(\mathrm{n}=135) \\
0.016\end{array}$} & \multirow{2}{*}{$\begin{array}{l}\text { Toba (2) } \\
(\mathrm{n}=19)\end{array}$} & \multirow{2}{*}{$\begin{array}{c}\text { Toba }(3) \\
(\mathrm{n}=86)\end{array}$} & \multirow{2}{*}{$\begin{array}{c}\text { Buenos Aires } \\
(\mathrm{n}=365)\end{array}$} \\
\hline DRB1*01 & 01 & & & & & & & \\
\hline \multirow[t]{2}{*}{ DRB $1 * 03$} & 0301 & & 0.026 & & 0.026 & & 0.006 & 0.110 \\
\hline & 0302 & & & & & 0.030 & & \\
\hline \multirow[t]{12}{*}{ DRB1*04 } & 0401 & 0.009 & & & & & 0.006 & 0.029 \\
\hline & 0402 & & & & & & & 0.017 \\
\hline & $0403^{\wedge}$ & 0.018 & & 0.021 & 0.034 & & 0.052 & 0.014 \\
\hline & $0404^{\wedge}$ & 0.009 & 0.105 & 0.110 & 0.054 & 0.030 & 0.058 & 0.017 \\
\hline & 0405 & & & & 0.004 & & 0.006 & 0.005 \\
\hline & $0407^{\wedge}$ & 0.053 & & & 0.062 & 0.061 & 0.081 & 0.019 \\
\hline & 0408 & & & & & & & 0.010 \\
\hline & 0409 & & & & & & & 0.005 \\
\hline & 0410 & & & & & & 0.006 & 0.005 \\
\hline & $0411^{\wedge}$ & 0.045 & 0.215 & 0.076 & 0.062 & 0.093 & 0.012 & 0.005 \\
\hline & 0413 & & & & & & & 0.002 \\
\hline & $0417^{\wedge}$ & & 0.080 & 0.122 & 0.090 & 0.061 & 0.041 & \\
\hline DRB1*07 & 0701 & 0.018 & 0.026 & 0.011 & 0.015 & 0.093 & 0.052 & 0.137 \\
\hline \multirow[t]{7}{*}{ DRB1*08 } & 0801 & & & & & & 0.006 & 0.014 \\
\hline & $0802^{\wedge}$ & 0.107 & 0.110 & 0.183 & 0.223 & 0.126 & 0.203 & 0.027 \\
\hline & 0803 & & & & & & & 0.005 \\
\hline & 0804 & 0.026 & 0.026 & & & & & 0.010 \\
\hline & 0806 & & & & & & & 0.002 \\
\hline & $0807^{\wedge}$ & 0.009 & & & & & & 0.012 \\
\hline & 0808 & & & & & & & 0.002 \\
\hline DRB1*09 & $0901^{\wedge}$ & 0.018 & 0.053 & & 0.011 & & 0.017 & 0.019 \\
\hline $\mathrm{DRB} 1 * 10$ & 1001 & & & & 0.004 & & & 0.012 \\
\hline \multirow[t]{4}{*}{ DRB1*11 } & 1101 & & 0.026 & & & & 0.012 & 0.063 \\
\hline & 1102 & & & & & & & 0.007 \\
\hline & 1103 & & & & & & & 0.010 \\
\hline & 1104 & & & & 0.037 & & & 0.031 \\
\hline
\end{tabular}


Table 3 (cont.)

\begin{tabular}{|c|c|c|c|c|c|c|c|c|}
\hline \multirow{2}{*}{$\begin{array}{l}\text { Alleles } \\
\text { HLA-DRB1 }\end{array}$} & & \multicolumn{7}{|c|}{ Populations } \\
\hline & & $\begin{array}{c}\text { Chiriguano } \\
(\mathrm{n}=56)\end{array}$ & $\begin{array}{c}\text { Wichi (2) } \\
(\mathrm{n}=19)\end{array}$ & $\begin{array}{c}\text { Wichi (3) } \\
(\mathrm{n}=49)\end{array}$ & $\begin{array}{l}\text { Toba (1) } \\
(\mathrm{n}=135)\end{array}$ & $\begin{array}{l}\text { Toba (2) } \\
(\mathrm{n}=19)\end{array}$ & $\begin{array}{l}\text { Toba (3) } \\
(\mathrm{n}=86)\end{array}$ & $\begin{array}{c}\text { Buenos Aires } \\
\quad(n=365)\end{array}$ \\
\hline \multirow[t]{3}{*}{$\mathrm{DRB} 1 * 11$} & 1106 & & & & & & & 0.002 \\
\hline & 1108 & & & & & & & 0.002 \\
\hline & 1115 & & & & & & & 0.002 \\
\hline $\mathrm{DRB} 1 * 12$ & 12 & 0.045 & & & & & & 0.010 \\
\hline \multirow[t]{5}{*}{ DRB1*13 } & 1301 & & & 0.011 & 0.008 & & 0.012 & 0.056 \\
\hline & 1302 & 0.009 & & & & & 0.017 & 0.058 \\
\hline & 1303 & & & & 0.004 & & & 0.010 \\
\hline & 1305 & & & & & & & 0.005 \\
\hline & 1307 & & & & & & & 0.002 \\
\hline \multirow[t]{5}{*}{$\mathrm{DRB} 1 * 14$} & 1401 & & & & 0.004 & & 0.006 & 0.022 \\
\hline & $1402^{\wedge}$ & 0.214 & 0.186 & 0.264 & 0.106 & 0.093 & 0.145 & 0.014 \\
\hline & 1404 & & & & & & & 0.002 \\
\hline & $1406^{\wedge}$ & 0.196 & 0.121 & 0.171 & 0.237 & 0.272 & 0.192 & 0.005 \\
\hline & 1409 & & 0.026 & & & & & \\
\hline DRB $1 * 15$ & 15 & 0.027 & & 0.022 & 0.004 & 0.123 & 0.006 & 0.094 \\
\hline \multirow[t]{4}{*}{ DRB1*16 } & 1601 & & & & & & & 0.036 \\
\hline & $1602^{\wedge}$ & 0.179 & & & 0.023 & & 0.006 & 0.007 \\
\hline & 1604 & 0.009 & & & & & & \\
\hline & 1605 & & & & & & & 0.002 \\
\hline
\end{tabular}

^: Most frequent alleles in Amerindian populations. For references, see Table 2.

DRB1*1102, DRB1*1104, DRB1*1301, DRB1*1302 and DRB1*1601, Table 1). In contrast, Wichi SV and Lengua showed $100 \%$ of Amerindian alleles and, therefore, the genetic diversity was much higher in Mapuche $(\mathrm{H}=0.91)$ and Tehuelche $(\mathrm{H}=0.85)$ than in Wichi SV $(\mathrm{H}=0.75)$ and Lengua $(H=0.56)$. As usual in human populations, the intrapopulational variation was high and explained $86 \%$ of the total genetic variability, while the gene differentiation coefficient diversity (Gst') was 17\%.

Our data were compared with those obtained in six Amerindian groups of the Gran Chaco region of Argentina and also with a sample of European origin from the city of Buenos Aires, to evaluate the effect of admixture
(Tables 2 and 3). The results showed a pronounced divergence among these regions. In general, smaller genetic distances were observed among the Chaco Populations and also between the Mapuche and Tehuelche groups. Almost all populations showed clear-cut differences with regard to the sample of Buenos Aires. However, due to the high admixture of non-Amerindian genes of European origin, the Mapuche and Tehuelche presented much smaller or only minor genetic distances from the Buenos Aires group (Table 4). The genetic distance dendrogram (Figure 2) shows that the Patagonian-Buenos Aires populations are clustered together, separated from all the Chaco populations.

Table 4 - Genetic distances (DA) for ten populations of Argentina.

\begin{tabular}{|c|c|c|c|c|c|c|c|c|c|c|}
\hline & Mapuche & Tehuelche & Wichi SV & Lengua & Chriguano & Wichi (2) & Wichi (3) & Toba (1) & Toba (2) & Toba (3) \\
\hline Tehuelche & 0.174 & & & & & & & & & \\
\hline Wichi SV & 0.785 & 0.671 & & & & & & & & \\
\hline Lengua & 0.674 & 0.647 & 0.163 & & & & & & & \\
\hline Chiriguano & 0.592 & 0.550 & 0.288 & 0.443 & & & & & & \\
\hline Wichi (2) & 0.357 & 0.307 & 0.339 & 0.228 & 0.330 & & & & & \\
\hline Wichi (3) & 0.632 & 0.558 & 0.160 & 0.300 & 0.137 & 0.287 & & & & \\
\hline Toba (1) & 0.377 & 0.398 & 0.232 & 0.293 & 0.199 & 0.217 & 0.130 & & & \\
\hline Toba (2) & 0.555 & 0.496 & 0.278 & 0.344 & 0.244 & 0.265 & 0.149 & 0.170 & & \\
\hline Toba (3) & 0.351 & 0.300 & 0.283 & 0.307 & 0.250 & 0.204 & 0.165 & 0.084 & 0.193 & \\
\hline Buenos Aires & 0.341 & 0.427 & 0.815 & 0.809 & 0.593 & 0.517 & 0.649 & 0.485 & 0.567 & 0.387 \\
\hline
\end{tabular}






Figure 2 - NJ dendrogram of the genetic distances (DA) among the analysed populations. For identifications and references, see Table 2 .

\section{Discussion}

The results obtained show similarities and differences in the genetic composition of the Gran Chaco and Patagonia populations.

Comparing the data obtained with those of other American indigenous groups, we observed that allele DRB1*0802 was found in Central and South America at high frequencies in the Ijka (62\%) of Colombia (Trachtenberg et al., 1996) and in the Guarani (50\%) and Kaingang (50\%) of Brazil (Petzl-Erler, 1997; Tsuneto et $a l ., 2003)$. In the Indians from Argentina, this allele presented mean frequencies of $14 \%$ to $17 \%$ in the Wichi of Orán (Province of Salta), in the Toba that migrated to Rosario city (Province of Santa Fe) and in other Toba and Wichi groups from northern Argentina (Cerna et al., 1993; Pando, 1998; Marcos, 2000). In our study, its prevalence was lower, with a variation range between $2 \%$ in the Wichi SV and $11 \%$ in the Tehuelche.

Allele DRB1*1402 was present at high frequencies in all four communities studied, similar to those observed in North American $($ Zuni $=32 \%$, Tlingit $=52 \%)$ and in other South American $($ Kogui $=17 \%$; Nukak $=65 \%)$ populations (Salzano, 2002).

Likewise, in the Wichi SV group, the frequency of allele DRB1*0403 (10\%) was similar to those found in the Wayuu from Colombia (15\%) and in the Yukpa from Venezuela (10\%) (Petzl-Erler et al., 1997), whereas the mean frequency of this allele has been reported to be $3 \%$ in Wichi, Toba and Chiriguano groups of the Argentinean Chaco region (Cerna et al., 1993; Pando, 1998; Marcos, 2000).

The DRB1*0407 variant was not detected in the Wichi SV and Lengua, but presented high frequencies in the Mapuche (20\%) and Tehuelche (32\%) samples, in concordance with the variation range observed in North, Central and South America (19\%-45\%) (Salzano, 2002). In addition, allele DRB1*0901, which was detected only in the Mapuche (7\%) and Tehuelche (9\%), was also detected in the Quechua (18\%) and in the Guarani (11\%) of Peru and Brazil (Tsuneto et al., 2003), and at much lower frequen- cies in indigenous groups of the Argentinean Chaco (Cerna et al., 1993; Pando, 1998).

On the other hand, we detected the DRB1*1406 allele only in the Wichi SV (42\%) and Lengua (65\%) groups. These elevated frequencies were also observed in other populations of the Gran Chaco of Argentina: Wichi, Toba, Pilagá and Chiriguano, with a variation range going from $12 \%$ to $27 \%$ (Cerna et al., 1993; Pando, 1998; Marcos, 2000). This allele was also found in some native Latin American groups such as the Terena (11\%) of Brazil (Lazaro et al., 1999) and, at lower frequencies (6\%-10\%), in the Mixe, Zapoteco and Mixteco of Mexico (Petzl-Erler et al., 1997).

Allele DRB1*1602, which presented a variation range of $2 \%$ to $16 \%$ in Lengua, Mapuche and Tehuelche, was also detected by Cerna et al. (1993) in the Toba (2\%), in the Chiriguano Indians (18\%; Pando, 1998) of Orán, Province of Salta, Argentina, in the Mixe of Central America $(31 \%)$, and in several South Amerindian populations such as the Wayuu (14\%) and the Bari (40\%) (Salzano, 2002).

It is worth mentioning that allele DRB $1 * 0417$ was detected for the first time in the Wichi and in the Toba by Cerna et al. (1993), Zhang et al. (1993) and in the Wichi studied by us. This allele was not observed in any other Amerindian populations and therefore we believe, in agreement with these authors, that this variant is original of the Argentinean Chaco Region.

In summary, based on the comparative analysis performed, we can conclude that most indigenous communities studied here share alleles with Amerindian populations of North, Central and South America. It should also be mentioned that the allelic variants detected here (DRB1*0403, *0405, *0802, *0901, *1402, *1406, *1602, $\mathrm{DRB} 1 * 12$ and DRB1*15) are frequent in Oriental populations (Grahovac et al., 1998; Tokunaga et al., 2001), mainly of northeast Asia, which is in concordance with the Asian origin of the American settlement.

On the other hand, the genetic distance dendrogram (Figure 2) shows that the Patagonian-Buenos Aires groups are clustered together and separated from all the Chaco populations. This topology is coherent with the geographic distribution and the interethnic relationships of the analysed groups. Thus, the strong biological affinities among the indigenous populations of Patagonia can be supported on the basis of the ethnic-historical information available. The contact between the Mapuche and Tehuelche populations began in the XVI century with the arrival of the Araucanian people in the Pampa and Patagonia regions. During this process, the Tehuelche incorporated the Mapuche language, as well as several cultural features. Thus, a major gene flow occurred through marriage, trade and political network (Mandrini, 1988; Nacuzzi, 1998). Likewise, these populations had intense contact with Spanish colonists ever since the XVIII century, mainly through trade relations and 
also upon conflictive and tense situations, when the seizing of captives made up the main axis for mating between natives and Europeans (Socolow, 1992). These facts could partly explain most of the genetic diversity observed in the Mapuche and Tehuelche Indians. In this sense, it is also known that in the communities of Aguada Guzmán and Cerro Policía there was a strong gene flow with non-Amerindians, due to the contacts established with people from urban centres such as the city of General Roca (Province of Río Negro) (Goicoechea et al., 2000). Regarding the Tehuelche community of El Chalía, the presence of Europeans can be verified by the historical and demographic information available, given that they participated as colonists in the foundation of this settlement (Carnese et al., 2002).

We did not have our own demographic data on the Chaco populations to allow us estimating the biological relationships among the groups studied. However, historical and anthropological information shows that the inhabitants of the Chaco kept extensive trade and cultural relationships that could encourage interethnic marriages with other Andean, Amazonian and Mesopotamian groups (Metraux, 1946; Dejean et al., 2004). Therefore, the gene flow mechanism could explain the strong genetic affinities observed between the Wichi and Lengua groups. Nevertheless, the lower genetic diversity detected in these groups seems to contradict this explanation, because an interethnic gene flow leads to an increase in the intrapopulational genetic variability. Therefore, these results could be explained by a combined action of gene flow and genetic drift. This mechanism may have influenced mainly the Lengua group, as its lower biological diversity $(\mathrm{H}=0.56)$ and its pronounced deficiency of heterozygotes seem to suggest. Previous data of STR markers obtained in the same populations also suggest that genetic drift could be the most important mechanism in the determination of the biological variability of Chaco populations (Catanesi et al., 2006). However, the low diversity found in this group could also be due to the small sample size. It is known that natural selection has a certain effect on HLA loci, which can produce some distortion and lead to an erroneous assessment of the biological relations among populations. It should however be emphasized that our results are in concordance with those obtained in previous studies performed in the same population, using blood group determination and mitochondrial and nuclear DNA markers (Goicoechea et al., 2001b; Carnese et al., 2003; Catanesi et al., 2006). This concordance, in turn, ratifies the usefulness of the HLA-DRB1 locus in genetic population studies.

\section{Acknowledgments}

We especially thank Drs. Leonardo Fainboim and Yanina Marcos from the Immunogenetic Service of the Hospital de Clínicas “José de San Martín”, UBA, for helping us to determine the HLA markers, and Dr. Alicia S.
Goicoechea for constructive suggestions. The Indian leaders and the subjects of the investigation were adequately informed about the aims of the study and gave their approval, which is gratefully acknowledged. Financial support was provided by the Consejo Nacional de Investigaciones Científicas y Técnica (CONICET, PIP 5393) and the Universidad de Buenos Aires (UBACyT F044).

\section{References}

Acreche N, Caruso G and Albeza M (1996) Distancias genéticas en poblaciones del NOA. Rev Arg Antrop Biol 1:139-152.

Bignon J and Fernandez-Viña M (1997) Protocols of the 12th International Histocompatibility Workshop for typing of HLA class II alleles by DNA amplification by the polymerase chain reaction (PCR) and hybridization with sequence specific oligonucleotide probes (SSOP). In: Charron D (ed) Genetic Diversity of HLA. Functional and Medical Implications. Medical and Scientific International Publisher, Sèvres, pp 584-595.

Carnese F, Caratini A and Goicoechea A (2002) Interethnic relations in Native-American populations of Argentine Patagonia: A genetic demographic analysis. In: Briones $\mathrm{C}$ and Lanata J (eds) Contemporary Perspectives on the Native Peoples of Pampa, Patagonia and Tierra del Fuego. Westport, Connecticut, pp 121-134.

Carnese F, Avena S, Goicoechea A, Dejean C, Sevin A and Dugoujon J (2003) Sistemas Gm y Km en poblaciones aborígenes de la Patagonia Argentina. In: Aluja M, Malgosa A and Nogués R (eds) Antropología y Biodiversidad. Bellaterra Press, Barcelona, pp 67-73.

Catanesi C, Tourret N, Carnese F and Vidal Rioja L (2006) South American Amerindian diversity at the vWA STR locus. J Basic Appl Genet 17:35-40.

Cerna M, Falco M, Friedman H, Maccagno A, Raimondi E, Fernández-Viña M and Stastny P (1993) Differences in HLA class II alleles of isolated South American Indian populations from Brazil and Argentina. Hum Immunol 37:213220.

Dejean C, Crouau-Roy B, Goicoechea A, Avena S and Carnese F (2004) Genetic variability in Amerindian populations of Northern Argentina. Genet Mol Biol 27:489-495.

Excoffier L and Slatkin M (1995) Maximum-likelihood estimation of molecular haplotype frequencies in a diploid population. Mol Biol Evol 12:921-927.

Fainboim L, Satz M and Geffner J (1999) Introducción a la Inmunología Humana. 4th edition. Editorial Médica Panamericana, Buenos Aires, 389 pp.

Fernandez-Viña M, Lázaro A, Marcos C, Nulf C, Raimondi E, Haas E and Stastny P (1997) Dissimilar evolution of B-locus versus A-locus and class II loci of the HLA region in South American Indian tribes. Tissue Antigens 50:233-250.

Ginther C, Corach D, Penacino G, Rey J, Carnese F, Hutz M, Anderson A, Just J, Salzano F and King M (1993) Genetic variation among the Mapuche Indians from the Patagonian region of Argentina. In: Pena SD, Chakraborty R, Epplen JT and Jeffreys AJ (eds) Mitochondrial DNA Sequence Variation Allele Frequencies of Several Nuclear Genes. Birkhäuser Verlag, Basel, pp 211-219.

Goicoechea A, Soria M, Haedo A, Crognier E and Carnese F (1996) Distancias genéticas en poblaciones aborígenes de la Argentina. Rev Arg Antrop Biol 1:153-166. 
Goicoechea A, Carnese F, Caratini A, Avena S, Salaberry M and Salzano F (2000) Demography, genetic diversity and population relationships among Argentinean Mapuche indians. Genet Mol Biol 23:513-518.

Goicoechea A, Carnese F, Dejean C, Avena S, Weimer T, Estalote A, Simoes M, Palatnik M, Salamoni P, Salzano F et al. (2001a) New Genetic Data on Amerindians from the Paraguayan Chaco. Am J Hum Biol 13:660-667.

Goicoechea A, Carnese F, Dejean C, Avena S, Weimer T, Franco M, Callegari-Jacques S, Estalote A, Simoes M, Palatnik M et al. (2001b) Genetic relationships between Amerindian populations of Argentina. Am J Phys Anthropol 115:133143.

Greenberg J (1987) Language in the Americas. Stanford University Press. Stanford, 458 pp.

Grahovac B, Sukernik R, O'hUigin C, Zaleska-Rutczynska Z, Blagitko N, Raldugina O, Kosutic T, Satta Y, Figueroa F, Takahata N et al. (1998) Polymorphism of the HLA class II loci in Siberian populations. Hum Genet 102:27-43.

Guo S and Thompson E (1992) Performing the exact test of Hardy-Weinberg proportion for multiple alleles. Biometrics 48:361-372.

Haas E, Salzano F, Araujo H, Grossman F, Barbetti A, Weimer T, Franco M, Verruno L, Nasif O, Morales V et al. (1985) HLA antigens and other genetic markers in the Mapuche Indians of Argentina. Hum Hered 35:306-313.

Lazaro A, Moraes M, Marcos C, Moraes J, Fernández-Viña M and Stastny P (1999) Evolution of HLA-class I compared to HLA-class II polymorphism in Terena, a South-American Indian tribe. Hum Immunol 60:1138-1149.

Loukotka C (1968) Classification of South American Indian Languages. University of California, Los Angeles, $453 \mathrm{pp}$.

Mandrini R (1988) La sociedad indígena de las pampas en el siglo XIX. In: Lischetti M (ed) Manual de Antropología. EUDEBA, Buenos Aires.

Metraux A (1946) Ethnography of the Gran Chaco. In: Steward J (ed) Handbook of South American Indians. Indians of the Gran Chaco. Bureau of American Ethnology Bulletin 143, Smithsonian Institution, v. I, part 2, pp 197-370.

Nacuzzi L (1998) Identidades Impuestas. Tehuelches, Aucas y Pampas en el Norte de la Patagonia. Sociedad Argentina de Antropología, Buenos Aires, 268 pp.

Nei M (1973) Analysis of gene diversity in subdivided populations. Proc Natl Acad Sci USA 70:3321-3332.

Nei M (1986) Definition and estimation of fixation indices. Evolution 40:643-645.

Nei M, Tajima F and Tateno Y (1983) Accuracy of estimated phylogenetic trees from molecular data. J Mol Evol 19:927943.

Ota T (1993) DISPAN: Genetic distance and phylogenetic analysis. Pennsylvania State University, Pennsylvania.

Pando M (1998) Estudio molecular de la distribución de alelos HLA-DR-DQ en poblaciones normales argentinas y en pacientes con hepatitis crónica autoinmune. Doctoral Thesis, Facultad de Ciencias Exactas y Naturales. Universidad de Buenos Aires.

Petzl-Erler M (1997) Guaraní Amerindian Brazil normal. In: Terasaki P and Gjertson D (eds) HLA 1997. Tissue Typing Laboratory, Los Angeles, pp 291.

Petzl-Erler M, Gorodezky C, Layrisse Z, Klitz W, Fainboim L, Vullo C, Bodmer JG, Egea E, Navarrete C, Infante E et al.
(1997) Anthropology report for region Latin-America: Amerindian and admixed populations. In: Charron D (ed) Genetic Diversity of HLA. Functional and Medical Implications. Medical and Scientific International Publisher, Sèvres, pp 337-345.

Pirosky I, Cantora M, Vellard J, Braunstein J and Alessandria J (1983) Análisis genético de una población indígena toba. Estudio de la frecuencia del HLA-DR. Medicina 43:281284.

Saitou N and Nei M (1987) The neighbor-joining method: A new method for reconstructing phylogenetic trees. Mol Biol Evol 4:406-425.

Salzano F (2002) Molecular variability in Amerindians: Widespread but uneven information. An Acad Bras Cienc 74:223-263.

Schneider S, Roessli D and Excoffier L (2000) ARLEQUIN: Software for population genetics data analysis. Genetics and Biometry Laboratory. Department of Anthropology, University of Geneva.

Socolow S (1992) Spanish captives in Indian societies: Cultural contact along the Argentine frontier, 1600-1835. Hispanic American Historical Review 72:73-99.

Tokunaga K, Ohashi J, Bannai M and Juji T (2001) Genetic link between Asians and Native Americans: Evidence from HLA genes and haplotypes. Hum Immunol 62:1001-1008.

Trachtenberg E, Keyeux G, Bernal J, Rhodas M and Erlich H (1996) Results of Expedición Humana. I. Analysis of HLA Class II (DRB1-DQA1-DQB1-DPB1) alleles and DR-DQ haplotypes in nine Amerindian populations from Colombia. Tissue Antigens 48:174-181.

Travers P (2000) Immune recognition and the MHC. In: Bidwell J and Navarrete $\mathrm{C}$ (eds) Histocompatibility Testing. Imperial College Press, London, pp 11-39.

Tsuneto L, Probst C, Hutz M, Salzano F, Rodriguez-Delfin L, Zago M, Hill K, Hurtado A, Ribeiro-dos-Santos A and Petzl-Erler M (2003) HLA class II diversity in seven Amerindian populations. Clues about the origins of the Aché. Tissue Antigens 62:512-526.

Valory D (1968) Notas sobre la antropología y demografía de las poblaciones fueguinas. Am Indig 28:653-674.

Vullo C, Celis E, Serra H and Riera C (1984) Study of HLA system in a Mataco population: A geographically isolated American indian tribe. Tissue Antigens 23:33-40.

Vullo C, Delfino L, Angelini G and Ferrara G (1992) HLA polymorphism in a Mataco South American indian tribe: Serology of class I and II antigens. Molecular analysis of class II polymorphic variants. Hum Immunol 35:209-214.

Zhang S, Fernandez-Viña M, Falco M, Cerna M, Raimondi E and Stastny P (1993) A novel HLA-DRB1 allele (DRB1*0417) in South American Indians. Immunogenetics 38:463.

\section{Internet Resources}

Marcos C (2000) HLA-DRB1 data of a Toba population from Rosario city, Santa Fé Province, and Buenos Aires urban groups, Argentina. Available at http://www.allelefrequencies.net (July, 2008).

Associate Editor: Francisco Mauro Salzano

License information: This is an open-access article distributed under the terms of the Creative Commons Attribution License, which permits unrestricted use, distribution, and reproduction in any medium, provided the original work is properly cited. 